\title{
Proses Berpikir Kreatif Siswa dalam Pengajuan Masalah Matematika
}

\author{
Akhmad Faisal Hidayat ${ }^{1}$, Peni Anggareni ${ }^{2}$ \\ ${ }^{1}$ (Pendidikan Matematika, Universitas Batanghari) \\ ${ }^{2}$ (SMP Negeri 7 Kota Jambi)
}

\begin{abstract}
This study aim to describe step of creative thinking processes in problem posing activity with IQ score below 120 . This study was do in $9^{\text {th }}$ grade Junior High School of Malang City with 3 subject who represent each category, are category 1 (IQ score 110 - 119), category 2 ( IQ score 100 - 109) dan category 3 (IQ score 90-99). The colect data instruments are TPMM and interview guidance. Interview is for eksploration creative thinking proceses of students when problem posing. The result of this study showed subjects of each criteria through only 3 steps creative thinking processes wich develop by Wallas, they are preparation, incubation, ilumination and verification. Preparation, subject commonly understand the givens. Each subject didn't through incubation. Although subjects was doing other things that were not relating with the MPPT, subject still thought about the task. Ilumination, each subject got idea to pose the problem. Verification, subjects comonly check questions and answers by count twice or check numbers in questions, even check the senteces of the questions which pose.
\end{abstract}

Keywords: Creative Thinking Processes, Mathematics Problem Posing

\begin{abstract}
Abstrak. Penelitian ini bertujuan untuk mendeskripsikan tahapan proses berpikir kreatif siswa dalam aktivitas pengajuan masalah dengan skor IQ di bawah 120 (90 - 119). Penelitian ini dilakukan di kelas IX SMP Negeri 5 Kota Malang dengan 3 orang subjek yang mewakili masing-masing kategori, yaitu kategori 1 (skor 1Q 110 - 119), kategori 2 (skor 1Q 100 - 109) dan kategori 3 (skor 1Q 90 - 99). Alat pengumpul data berupa TPMM dan pedoman wawancara. Wawancara dilakukan untuk mengungkapkan proses berpikir kreatif siswa dalam mengajukan masalah. Hasil penelitian menunjukkan bahwa subjek pada masing-masing kategori hanya melewati 3 tahap proses berpikir kreatif yang dikembangkan oleh Wallas, yaitu persiapan, iluminasi dan verifikasi. Tahap persiapan, subjek umumnya memahami situasi yang diberikan. Ketiga subjek pada masing-masing kategori tidak mengalami tahap inkubasi. Meskipun subjek mengerjakan hal lain yang tidak berhubungan dengan tugas, namun subjek tetap memikirkan tugas yang diberikan. Tahap iluminasi, masing-masing subjek mendapatkan ide pembuatan soal. Tahap verifikasi umumnya subjek memeriksa soal dan jawaban dengan menghitung jawaban dua kali atau memeriksa bilangan pada soal bahkan memeriksa redaksi soal yang diajukan.
\end{abstract}

Kata Kunci: Proses Berpikir Kreatif, Pengajuan Masalah Matematika

\section{PENDAHULUAN}

Penelitian ini dilatarbelakangi dengan ditemukannya fakta di lapangan bahwa terdapat siswa dengan skor IQ dibawah 120 yang memiliki potensi kreatif. Padahal menurut Teori Threshold, seseorang akan sangat sukses dalam kegiatan kreatif jika memiliki IQ di atas 120 (Hayes, 1989). Pada umumnya skor IQ dalam populasi dunia berada pada kisaran rata-rata IQ yakni 90 -119 (Syahnur, 2012). Selain itu, berdasarkan data skor IQ di SMP Negeri 5 Kota Malang, pada umunya siswa memiliki skor IQ di bawah 120. Dengan kata lain, siswa dengan skor IQ di bawah 120 yang akan dikembangkan berpikir kreatifnya.

Sejak tahun 2013, indonesia mengembangkan kurikulum 2013 dengan perbaikan yang dilakukan setiap tahunnya. Salah satu kompetensi yang dituntut menurut Pemendikbud Nomor 58 tahun 2014 adalah menjadi manusia yang kreatif (Kemdikbud, 2014). Dengan kata lain, salah satu kompetensi yang harus dimiliki siswa adalah berpikir kreatif. Namun kenyataannya, masih jarang guru-guru yang mengembangkan pembelajaran yang dapat mendorong berpikir kreatif siswa. Pada umumnya guru menganggap berpikir kreatif sebagai hal yang tidak penting dalam pembelajaran (Siswono, 2004).

Berpikir kreatif adalah aktivitas mental untuk menghasilkan ide baru dengan menggabungkan dan menerapkan ide sesuai dengan tujuan (Siswono, 2004). Selain itu, menurut Sukmadinata (2004) berpikir kreatif juga merupakan kebiasaan berpikir yang bersifat eksplorasi, imajinasi, intuisi dan menghasilkan pemikiran yang tak terduga. Dengan demikian, berpikir kreatif diperlukan dalam pembelajaran untuk menghasilkan ide baru yang tidak biasa.

Terdapat beberapa aspek untuk menilai berpikir kreatif, yaitu kelancaran, keluwesan, kebaruan (Torrance, 1969; Silver, 1997; Kontorovich dkk, 2011; Guilford dalam Sriraman \& Lee, 2011), elaborasi dan redefinisi (Torrance, 1969). Namun hanya tiga aspek berpikir kreatif yang digunakan dalam penelitian ini, yaitu kelancaran, keluwesan, dan kebaruan.

Salah satu aktivitas yang dapat mengembangkan dan mengidentifikasi berpikir kreatif adalah pengajuan masalah (English, 1997; Silver, 1997; Siswono, 2004; Kontorovich dkk, 2011; Bonotto \& Santo, 
2015). Pengajuan masalah merupakan aktivitas yang mendorong berpikir kreatif (English, 1997), bahkan lebih penting dari pemecahan masalah (Jay \& Perkins, 1997). Oleh sebab itu, dalam penelitian ini digunakan aktivitas pengajuan masalah untuk melihat dan mengidentifikasi berpikir kreatif.

Dalam penelitian ini, berpikir kreatif yang dimaksud adalah aktivitas mental yang menghasilkan ide baru (berupa soal matematika). Kelancaran adalah kemampuan mengajukan banyak soal matematika dalam kurun waktu tertentu. Keluwesan adalah kemampuan mengajukan tipe soal dan strategi pengajuan soal yang berbeda-berbeda. Tipe soal yang dimaksud dalam penelitian ini adalah soal yang dilihat dari jenis materi yang digunakan pada soal yang diajukan. Sedangkan strategi pengajuan soal yang dimaksud yaitu menerima informasi yang diberikan, mengubah informasi yang diberikan dan memperkenalkan jenis baru dari informasi yang diberikan. Kebaruan adalah kemampuan mengajukan soal baru hasil pengembangan soalsoal yang pernah dikerjakan sebelumnya, berupa soal tidak rutin atau open-ended. Soal tidak rutin adalah soal yang jarang dihadapi siswa di sekolah dan jarang menerapkan algoritma. Sedangkan soal open-ended adalah soal yang memiliki banyak solusi atau cara penyelesaiannya.

Berpikir kreatif dapat juga dikembangkan dengan perencanaan pengajaran yang baik (Gomez, 2007). Hal ini sejalan dengan Permendikbud nomor 103 tahun 2014 yaitu dalam proses pembelajaran guru harus menyediakan pembelajaran yang dapat memberikan kesempatan untuk mengembangkan ide, berpikir kreatif, dan kemandirian (Kemdikbud, 2014). Oleh sebab itu, guru memerlukan informasi tahapan proses berpikir kreatif siswa untuk merancang pembelajaran yang mengembangkan berpikir kreatif.

Tahapan proses berpikir kreatif yang digunakan dalam penelitian ini adalah model empat tahap yang dikembangkan oleh Wallas. Menurut Wallas ada 4 tahapan proses berpikir kreatif, yaitu tahap persiapan, tahap inkubasi, tahap iluminasi dan tahap verifikasi (Herring dkk, 2009; Siswono, 2004; Lau, 2011; Sriraman dkk, 2013). Tahap persiapan adalah tahap mendapatkan wawasan dalam mengahadapi masalah. Tahap inkubasi adalah tahap mengendapkan informasi, berpikir panjang, dan pelan-pelan untuk mencari ide. Tahap iluminasi adalah tahap memunculkan dan mengabungkan ide untuk mengajukan soal. Tahap verifikasi adalah tahap menulis dan menguji ide yang dihasilkan.

Dalam penelitian ini, peneliti memilih gambar geometri sebagai situasi yang diberikan. Pemilihan gambar geometri ini dikarenakan beberapa alasan. Pertama, bentuk geometri banyak terdapat disekitar siswa, sehingga diharapkan siswa lebih kreatif dalam mengajukan masalah. Kedua, geometri telah dipelajari siswa dari jenjang SD, sehingga diharapkan telah banyak pengetahuan siswa tentang geometri. Topik yang dipilih dalam penelitian ini adalah bangun datar. Melalui aktivitas pengajuan masalah matematika, diharapkan dapat dilihat kreativitas siswa sebagai hasil belajar matematika yang telah dilalui (Silver, 1997).

\section{METODE PENELITIAN}

Penelitian ini merupakan penelitian deskriptif eksploratif dengan pendekatan kualitatif. Penelitian ini mengambarkan tahapan proses berpikir kreatif siswa dalam aktivitas pengajuan masalah matematika. Data yang diperoleh berupa kata-kata dan perilaku dari subjek yang diamati. Subjek penelitian diharapkan dapat menyampaikan secara terbuka hal-hal yang dipikirkaan selama mengerjakan Tugas Pengajuan Masalah Matematika (TPMM). Pengumpulan data dilakukan dengan merekam secara audio visual ketika subjek mengerjakan TPMM dan merekam secara audio ketika wawancara. Wawancara dilakukan untuk mengungkapkan proses berpikir kreatif siswa dalam mengajukan masalah. Data yang diperoleh dianalisis dengan mentranskip data, menelaah data, mereduksi data, menggambar struktur proses berpikir kreatif dan membuat kesimpulan.

Penelitian ini dilakukan di kelas IX SMP Negeri 5 Kota Malang. Subjek penelitian ini adalah 3 siswa yang mewakili masing-masing kategori, yaitu kategori 1 (skor IQ 110 - 119), kategori 2 (skor IQ 100 - 109) dan kategori 3 (skor IQ 90 -99). Ketiga subjek tersebut dipilih berdasarkan skor IQ, hasil analisis Tugas Pengajuan Masalah Matematika (TPMM), kemampuan berkomunikasi dan kesediaan siswa menjadi subjek.

Instrumen pengumpulan data yang digunakan dalam penelitian ini adalah TPMM, pedoman wawancara, dan alat rekam. TPMM yang diberikan berupa gambar geometri dalam kehidupan sehari-hari. Namun, siswa diminta mengajukan soal matematika tidak hanya mengenai geometri tetapi juga mengenai materi yang pernah dipelajari sebelumnya. Selain mengajukan soal pada TPMM, siswa juga diminta untuk menuliskan jawaban soal yang diajukan. Analisis data hasil TPMM dilakukan dengan menganalisis soal yang dapat diselesaikan, kemudian dilihat berdasarkan indikator berpikir kreatif yaitu kelancaran, keluwesan 
dan kebaruan. Wawancara dilakukan berdasarkan 4 tahap proses berpikir kreatif yaitu persiapan, inkubasi, iluminasi dan verifikasi. Selain itu, wawancara yang dilakukan pada penelitian ini merupakan wawancara semi terstruktur dengan berbasis tugas. Oleh karena itu, pedoman wawancara memuat pertanyaan pokok dan pelaksanaan di lapangan tergatung pada hasil TPMM. Alat rekam yang digunakan berupa alat rekam audio-visual untuk merekam subjek penelitian ketika mengerjakan TPMM dan alat rekam audio ketika dilakukan wawancara. Berdasarkan hasil rekaman pada saat subjek penelitian mengerjakan TPMM, peneliti memperoleh data berupa perilaku siswa ketika mengerjakan TPMM, dan diperkuat dengan wawancara yang dilakukan.

Berikut gambar geometri pada TPMM yang diberikan pada siswa :

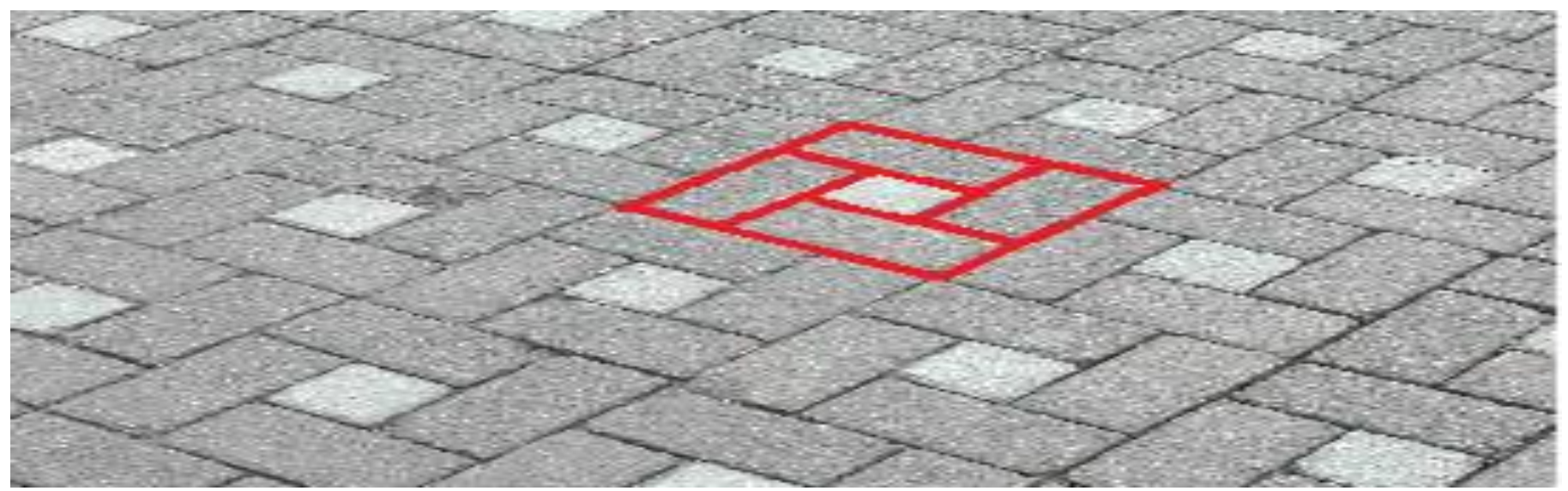

Gambar 1. Gambar Geometri Pada TPMM yang Diberikan

\section{HASIL DAN PEMBAHASAN}

TPMM tidak diberikan pada seluruh siswa kelas IX. TPMM ini diberikan pada siswa yang memiliki potensi kreatif dalam pembelajaran matematika. Dalam hal ini, peneliti meminta saran dari guru matematika di sekolah tersebut. Peneliti berasumsi jika TPMM ini diberikan pada seluruh siswa atau pun diberikan pada beberapa siswa (berdasarkan saran guru) akan diperoleh hasil yang tidak jauh berbeda. Hal ini diakukan dengan pertimbangan bahwa guru matematika tersebut lebih mengetahui kondisi siswanya, selain itu pemberian TPMM hanya pada beberapa siswa dapat memudahkan peneliti dalam mengamati proses berpikir kreatif siswa dalam mengajukan masalah matematika. Peneliti berdiskusi dengan guru matematika untuk memilih 9 siswa dengan potensi kreatif dalam pembelajaran matematika untuk mewakili masing-masing kategori. Selanjutnya 9 siswa tersebut diberikan TPMM. Berdasarkan hasil analisis soal yang diajukan siswa, peneliti memilih satu subjek paling kreatif pada setiap kategori. Berikut pemilihan subjek berdasarkan analisis soal yang diajukan siswa berdasarkan aspek kelancaran, keluwesan, dan kebaruan.

Tabel 1. Pemilihan Subjek Berdasarkan Analisis Soal yang Diajukan Berdasarkan Aspek Kelancaran, Keluwesan dan Kebaruan

\begin{tabular}{|c|c|c|c|c|c|c|c|c|}
\hline \multirow[t]{2}{*}{ Kategori } & \multirow{2}{*}{$\begin{array}{c}\text { Insial } \\
\text { Dan } \\
\text { Skor IQ }\end{array}$} & \multirow[t]{2}{*}{ Kelancaran } & \multicolumn{2}{|c|}{ Keluwesan } & \multicolumn{3}{|c|}{ Kebaruan } & \multirow[t]{2}{*}{ KET } \\
\hline & & & $\begin{array}{l}\text { Banyak } \\
\text { tipe soal }\end{array}$ & $\begin{array}{l}\text { Banyak } \\
\text { Strategi }\end{array}$ & $\begin{array}{c}\text { Soal tidak } \\
\text { rutin }\end{array}$ & $\begin{array}{l}\text { Soal open- } \\
\text { ended }\end{array}$ & $\begin{array}{c}\text { Soal } \\
\text { Baru }\end{array}$ & \\
\hline Kategori 1 & SL (118) & 6 & 4 & 1 & 1 & 0 & 1 & \\
\hline \multirow[t]{2}{*}{$(110-119)$} & RD (113) & 5 & 5 & 3 & 1 & 0 & 1 & \\
\hline & DN (110) & 6 & 4 & 3 & 3 & 2 & 3 & $\mathrm{~S}_{1}$ \\
\hline Kategori 2 & EN (108) & 6 & 5 & 2 & 0 & 0 & 0 & \\
\hline \multirow[t]{2}{*}{$(100-109)$} & BN (107) & 3 & 3 & 2 & 3 & 3 & 3 & $\mathrm{~S}_{2}$ \\
\hline & AN (103) & 3 & 3 & 2 & 2 & 0 & 2 & \\
\hline Kategori 3 & BS (99) & 5 & 3 & 2 & 1 & 0 & 1 & $\mathrm{~S}_{3}$ \\
\hline \multirow[t]{2}{*}{$(90-99)$} & DD (91) & 1 & 1 & 1 & 0 & 0 & 0 & \\
\hline & SH (90) & 4 & 2 & 1 & 0 & 0 & 0 & \\
\hline
\end{tabular}

\section{Deskripsi Proses Berpikir Kreatif pada Subjek Kategori 1}

Berdasarkan situasi yang diberikan, Subjek ketegori $1\left(\mathrm{~S}_{1}\right)$ mampu membuat 5 soal matematika. Selain itu, $S_{1}$ juga mampu menjawab soal yang dibuat dengan benar. Berikut soal yang diajukan oleh $S_{1}$. 


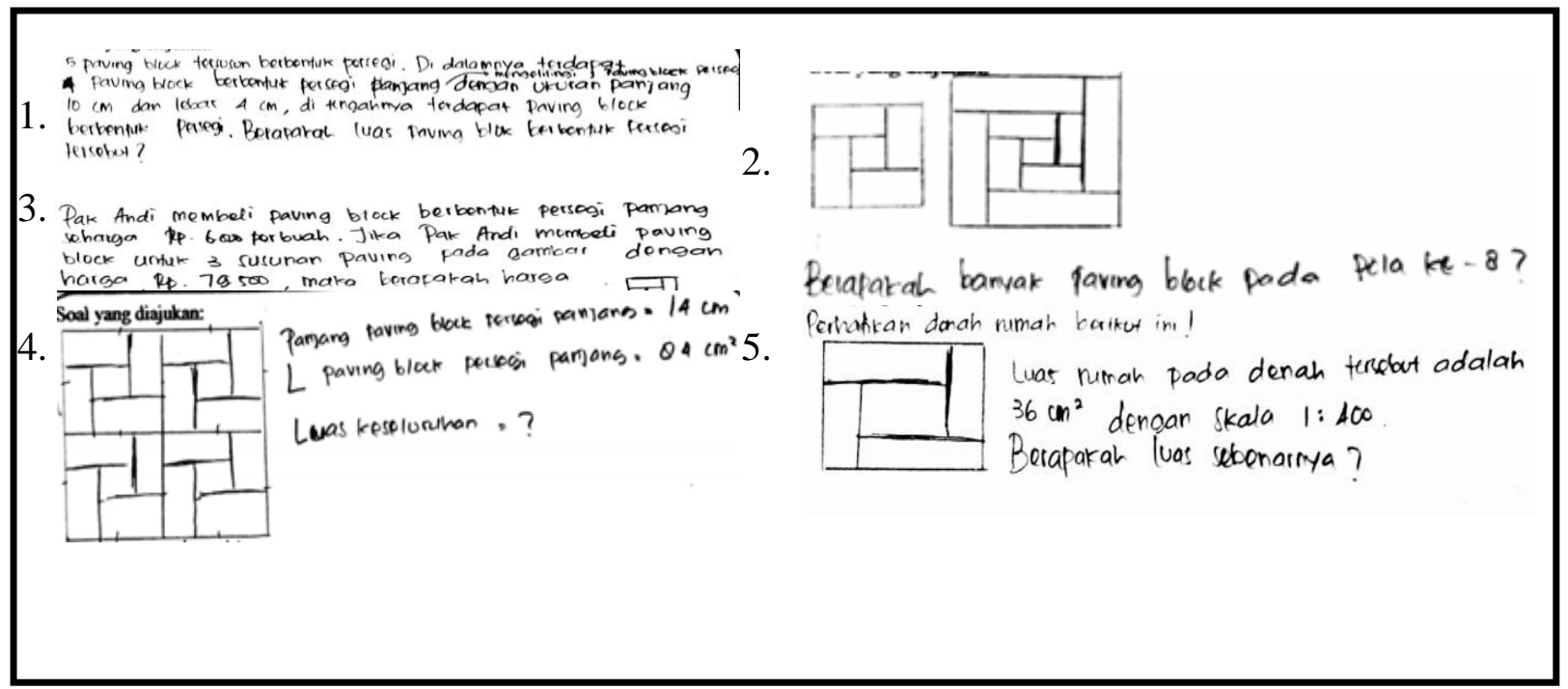

Gambar 2. Soal yang Diajukan $S_{1}$

Berdasarkan gambar di atas terlihat $S_{1}$ mengajukan 4 tipe soal dan menggunakan 3 strategi pengajuan masalah. Tipe soal yang diajukan yaitu mengenai luas bangun datar (soal nomor 1 dan 4), pola bilangan (soal nomor 2), Sistem Persamaan Linear Dua Variabel (soal nomor 3) dan Skala (soal noor 5). Sedangkan 3 strategi yang digunakan subjek yaitu menerima informasi yang diberikan, mengubah informasi yang diberikan, dan memperkenalkan jenis baru dari informasi yang diberikan. Pada soal nomor 1, 4 dan 5 subjek menggunakan gambar geometri sama persis dengan yang diberikan. Sedangkan pada soal nomor 2, subjek mengubah gambar geometri yang diberikan dengan menambah pola yang sama didalam persegi kecil yang ada pada gambar geometri yang diberikan. Selain itu, pada soal nomor 3 subjek memperkenalkan jenis baru dengan menambahkan informasi selain ukuran panjang, lebar dan luas, yaitu menambahkan informasi baru berupa harga. Untuk melihat proses berpikir kreatif $S_{1}$, berikut cuplikan wawancara dengan $S_{1}$.

$P \quad$ : Apa yang kamu pikirkan sebelum membuat soal nomor dua?

$S_{1} \quad$ : Kalau soal yang ini, saya bikinnya .. kan ini ada banyak bu .. jadi saya langsung kepikiran pola bilangan.. langsung kepikiran buat nyari suku ke berapa.

$P \quad$ : Mengapa pola bilangan yang kamu pikirkan?

$S_{1} \quad:$ Ya cari mudahnya juga sich.. kan tinggal cari pola ke-8, kan tinggal pake rumus.

$P \quad$ : Apa yang kamu lakukan untuk membuat soal ini?

$S_{1} \quad$ : Saya nambahin .. di rangakain 1 itu kayak yang digambar ini, terus yang rangkaian 2 saya nambahi satu rangkaian lagi di dalamnya gt bu.

$P \quad$ : Selain itu ngapain lagi?

$S_{1} \quad$ : Selain itu, saya menghitung ini banyak paving tiap satu rangkaian. Saya kan mikirnya kalau misal ditambah-tambahi gitu kan jumlah paving bloknya makin nambah makin nambah. Jadi pola ke-8 tu saya mikirnya ada berapa paving blok gitu.

\section{Deskripsi Proses Berpikir Kreatif pada Subjek Kategori 2}

Berdasarkan situasi yang diberikan, Subjek ketegori $2\left(\mathrm{~S}_{2}\right)$ mampu membuat 3 soal matematika. Selain itu, $S_{2}$ juga mampu menjawab soal yang dibuat dengan benar. Berikut soal yang diajukan oleh $S_{2}$. 


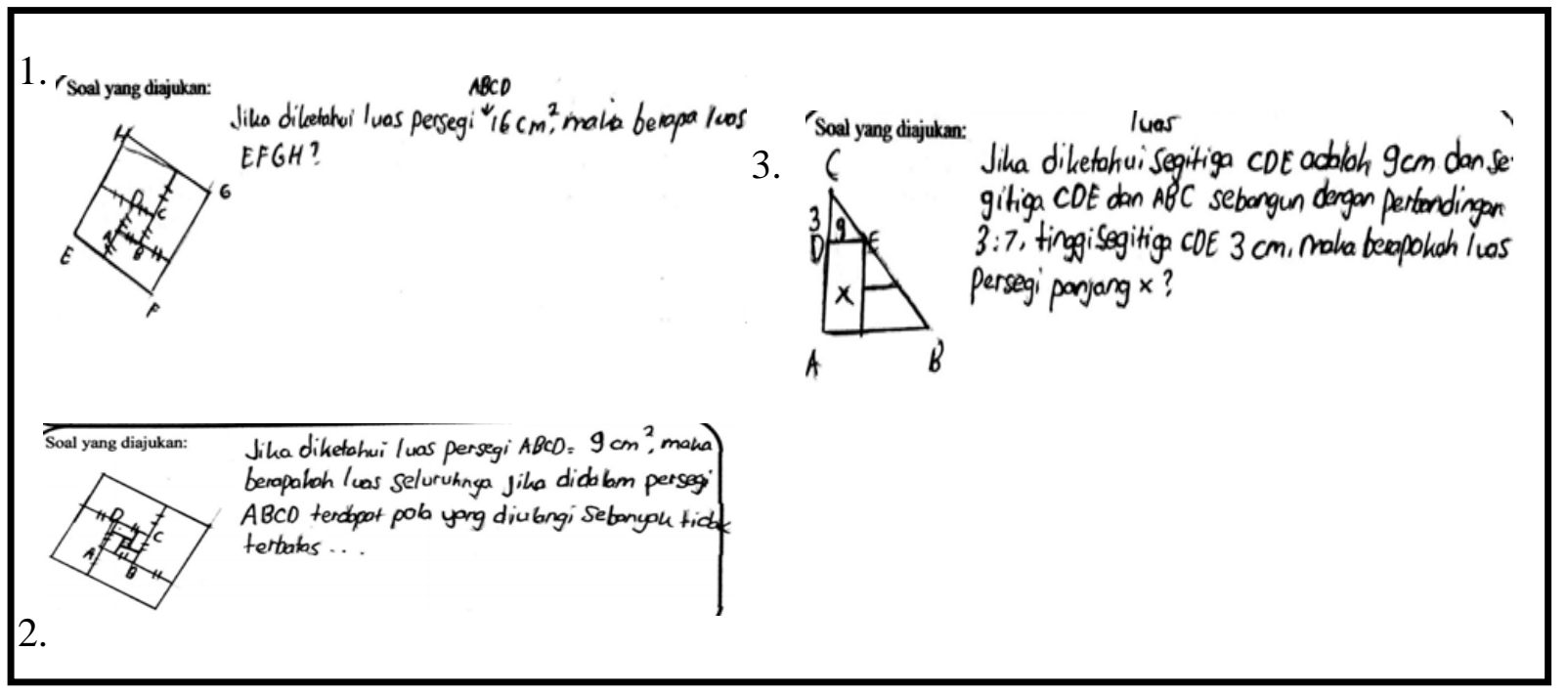

Gambar 3. Soal yang Diajukan $\mathrm{S}_{2}$

Berdasarkan gambar di atas terlihat $\mathbf{S}_{2}$ mengajukan 3 tipe soal dan menggunkan 2 strategi pengajuan masalah. Tipe soal yang diajukan yaitu luas bangun datar (soal nomor 1), pola bilangan (soal nomor 2) dan kesebangunan (soal nomor 3). Sedangkan 2 strategi yang digunakan $\mathrm{S}_{2}$ yaitu menerima informasi yang diberikan dan mengubah informasi yang diberikan. Pada soal nomor $1, \mathbf{S}_{2}$ hanya menggunakan gambar geometri yang diberikan. Sedangkan pada soal nomor 2 dan $3, \mathrm{~S}_{2}$ mengubah gambar geometri yang diberikan dengan menambah pola yang sama didalam persegi kecil (soal nomor 2) dan membagi dua gambar rangkaian persegi yang diberikan (soal nomor 3). Untuk melihat proses berpikir kreatif $\mathrm{S}_{2}$, berikut cuplikan wawancara dengan $\mathrm{S}_{2}$.

$P \quad$ : Apa yang kamu lakukan untuk membuat soal ini?

$\mathrm{S}_{2} \quad$ : Saya mencari bilangan dulu bu.

$P \quad$ : Bagaimana cara kamu memberikan luas ABCD tu $16 \mathrm{~cm} 2$, ada cari-cari dulu atau gimana?

$S_{2} \quad$ : Langsung bu..

$P \quad:$ Ada coret-coret dulu?

$S_{2} \quad:$ Gak ada bu.

$P \quad$ : Apa lagi yang kamu lakukan?

$S_{2} \quad$ : Menggambar ini (menunjuk gambar soal nomor 1), menulis sisi-sisi dengan tanda sama panjang dan luas yang diketahui pada soal bu. Kemudian saya menulis soalnya.

$P \quad$ : Sebelum menulis tu ngapain?

$S_{2} \quad$ : Memikirkan soal yang berhubungan dengan gambar ini.

$P \quad$ : Berarti kamu memikirkan soal yang akan dibuat atau soal yang dulu pernah dipelajari?

$S_{2} \quad$ : Yang akan dibuat.

$P \quad:$ Jadi, ide kalimat soal ini dari mana?

$S_{2} \quad$ : Dari saya sendiri bu.

\section{Deskripsi Proses Berpikir Kreatif pada Subjek Kategori 3}

Berdasarkan situasi yang diberikan, Subjek ketegori $3\left(\mathrm{~S}_{3}\right)$ mampu membuat 5 soal matematika. Namun terdapat 2 soal yang salah karena $S_{3}$ kurang teliti memeriksa soal dan jawaban yang diajukan. Berikut soal yang diajukan oleh $\mathrm{S}_{3}$. 


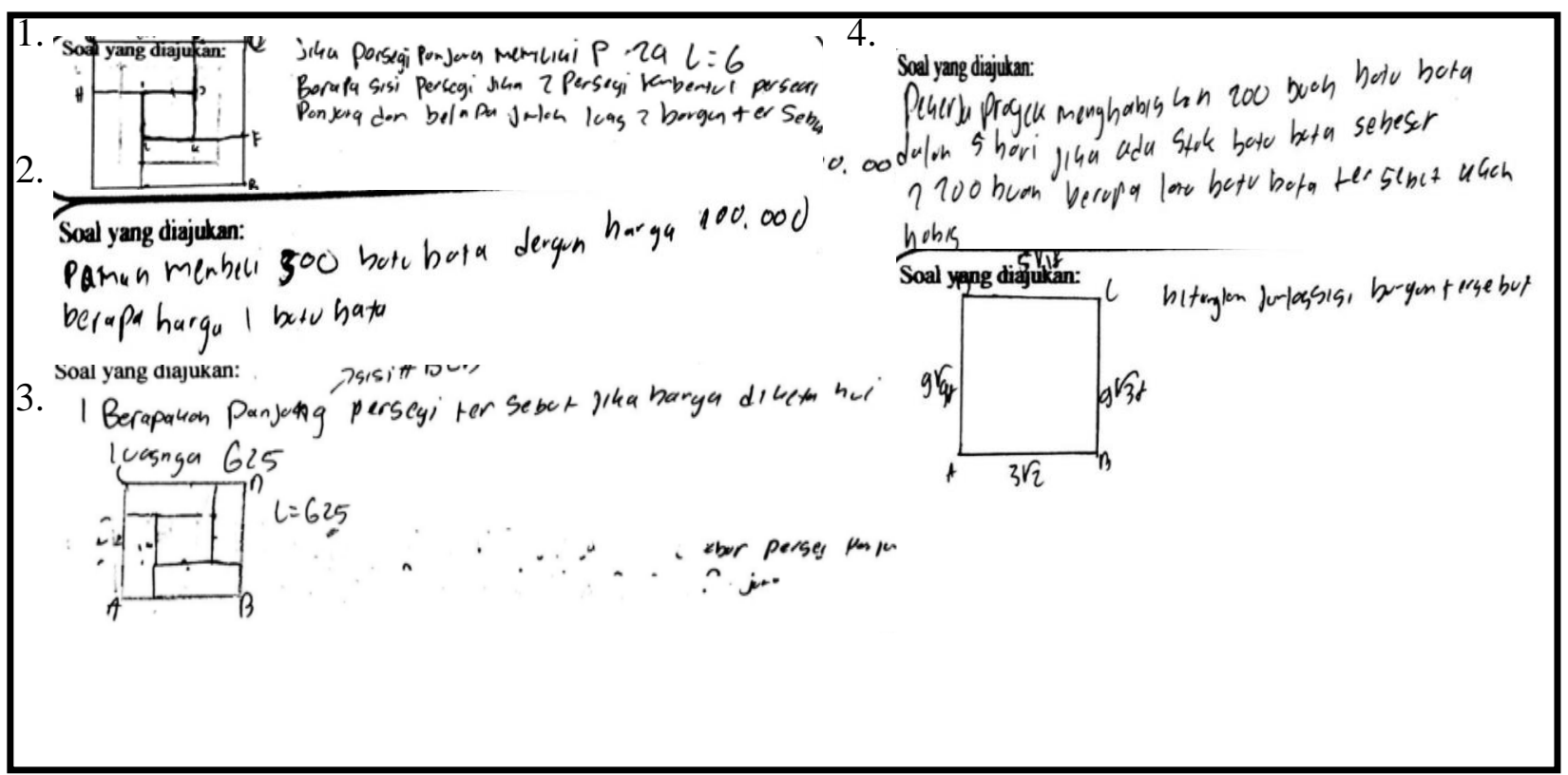

Gambar 4. Soal yang Diajukan $\mathrm{S}_{3}$

Berdasarkan gambar di atas terlihat $\mathrm{S}_{3}$ mengajukan 3 tipe soal dan menggunakan 2 strategi pengajuan masalah. Tipe soal yang diajukan yaitu bangun datar (soal nomor 1,3 dan 5), aritmetika (soal nomor 2) dan perbandingan (soal nomor 4). Sedangkan 2 strategi yang digunakan $S_{3}$ yaitu menerima informasi yang diberikan dan mengubah informasi yang diberikan. Pada soal nomor 1,3 dan $5, S_{3}$ hanya menggunakan gambar geometri yang diberikan. Sedangkan pada soal nomor 2 dan $4, \mathrm{~S}_{3}$ memperkenalkan jenis baru dengan menambahkan selain ukuran panjang, lebar dan luas, yaitu menambahkan informasi baru berupa banyak paving blok, harga atau waktu. $S_{3}$ menghubungkan paving blok dengan harga serta banyak paving blok dan waktu.

$\mathrm{S}_{3}$ mengubah gambar geometri yang diberikan dengan menambah pola yang sama didalam persegi kecil (soal nomor 2) dan membagi dua gambar rangkaian persegi yang diberikan (soal nomor 3). Untuk melihat proses berpikir kreatif $S_{2}$, berikut cuplikan wawancara dengan $S_{3}$.
$P \quad$ : Apa yang kamu pikirkan sebelum membuat soal nomor 1 ini?
$S_{3} \quad$ : Mencari soal yang sesuai dengan gambar tersebut.
$P \quad$ : Kenapa kok bisa buat soal itu?
$S_{3} \quad$ : Saya sudah sering lihat soal seperti ini di latihan-latihan soal untuk ujian nasional
$P \quad$ : Kenapa yang kamu pikirkan soal UN?
$S_{3} \quad$ : Karena kepikiran fokus UN bu.. Ya.. Jadi pas ngerjakan, pernah ngerjakan soal seperti ini jadi saya buat, seperti itu bu.
$P \quad$ : Apa yang pertama kali kamu lakukan untuk membuat soal ini?
$S_{3} \quad$; Gambar terus buat kalimat. Trus bilangnnya.
$P \quad$ : Menentukan bilangan itu apakah kamu coret-coret dikertas?
$S_{3} \quad$ : Gak, langsung menemukannya bu.

$\mathrm{S}_{1}, \mathrm{~S}_{2}$ dan $\mathrm{S}_{3}$ merupakan subjek yang paling kreatif pada masing-masing kategori skor IQ. Meskipun subjek penelitian ini memiliki IQ di bawah 120, namun $S_{1}, S_{2}$ dan $S_{3}$ mampu menunjukkan potensi kreatif dalam mengajukan masalah matematika. Berdasarkan Teori Threshold, seseorang yang memiliki IQ di atas 120 akan sangat sukses dalam kegiatan kreatif (Hayes, 1989). Subjek penelitian ini merupakan siswa dengan skor IQ di bawah 120. Berdasarkan tabel 1 terlihat bahwa pada masing-masing kategori tedapat subjek yang memiliki potensi kreatif. Menurut Siswono (2004) seseorang dikatakan kreatif jika memenuhi 3 aspek berpikir kreatif. Hal ini berarti, meskipun seseorang memiiliki IQ dibawah 120, bukan berarti seseorang itu tidak memiliki potensi kreatif. Hal ini sejalan dengan Kim (2005) yang menyatakan siswa dapat menjadi kreatif meskipun memiliki 
skor IQ rendah. Selain itu, berpikir kreatif juga dapat dikembangkan dengan perencanaan pengajaran yang baik (Gomez, 2007).

Peneliti membagi subjek dalam 3 kategori skor IQ, yaitu kategori 1 (skor IQ 110 - 119), kategori 2 (skor IQ 100 - 109) dan kategori 3 (skor IQ 90 - 99). Skor IQ $S_{1}, S_{2}$ dan $S_{3}$ berturut-turut adalah 110, 107 dan 99. $S_{1}, S_{2}$ dan $S_{3}$ merupakan subjek yang paling kreatif pada masing-masing kategori, namun terdapat perbedaan dalam tingkat kreatif masing-masing subjek. $S_{1}$ menunjukkan aspek kelancaran dan keluwesan lebih baik dibandingkan $S_{2}$ dan $S_{3}$. Selain itu, $S_{1}$ dan $S_{2}$ mampu menunjukkan aspek kebaruan lebih baik dari $S_{3}$. Meskipun $S_{2}$ mengajukan soal matematika paling sedikit (3 soal matematika) dan hanya terkait geometri, namun soal yang diajukan $\mathrm{S}_{2}$ memiliki tingkat kerumitan yang lebih dibandingkan dengan soal matematika yang diajukan $S_{1}$ dan $S_{3}$.

Dalam mengajukan soal matematika berdasarkan gambar geometri yang diberikan, pada umumnya subjek penelitian mampu menghasilkan soal dan jawaban yang benar, hanya $S_{3}$ yang melakukan kesalahan dalam membuat dan menjawab soal. Beikut keterangan kode yang digunakan pada struktur proses berpikir kreatif siswa dalam aktivitas pengajuan masalah.

\begin{tabular}{cl}
\hline Kode & \multicolumn{1}{c}{ Arti Kode } \\
\hline INF & Informasi \\
P1 & Mengetahui terdapat paving blok berbentuk persegi dan persegi panjang \\
P2 & Mengetahui masing-masing ukuran paving blok persegi panjang sama \\
P3 & Mengetahui masing-masing ukuran paving blok persegi panjang sama dengan dua kali paving blok persegi \\
P4 & Mengetahui 4 paving blok berbentuk persegi panjang dan 1 paving blok berbentuk persegi jika digabungkan dapat \\
& membentuk satu persegi besar \\
P5 & Mengetahui bahwa subjek diminta mengajukan soal atau masalah matematika beserta jawaban \\
I1 & Mengaitkan informasi yang diberikan dengan materi pelajaran yang telah dipelajari sebelumnya \\
I2 & Mengingat soal matematika yang pernah dikerjakan sebelumnya \\
I3 & Menentukan bilangan yang akan digunakan \\
I4 & Merangkai kalimat yang tepat untuk soal matematika yang akan diajukan \\
I5 & Memodifikasi gambar \\
L1 & Memperoleh ide bilangan yang akan digunakan pada soal(masalah) matematika \\
L2 & Memperoleh ide kalimat yang akan digunakan pada soal(masalah) matematika \\
L3 & Memperoleh ide tentang gambar yang akan digunakan pada soal(masalah) matematika \\
$\mathrm{M}_{\mathrm{n}}$ & Menulis soal matematika ke-n (n = 1, 2, 3,...) \\
$\mathrm{J}_{\mathrm{n}}$ & Menjawab soal matematika ke-n (n = 1, 2, 3,...) \\
V1 & Memeriksa jawaban dari soal soal matematika matematika yang diajukan \\
V2 & Memeriksa bilangan pada soal matematika yang diajukan \\
V3 & Memeriksa redaksi bahasa pada soal matematika yang diajukan
\end{tabular}

Berikut ini akan dipaparkan proses berpikir kreatif pada masing-masing subjek.

\section{Proses Berpikir Kreatif Subjek Kategori 1}

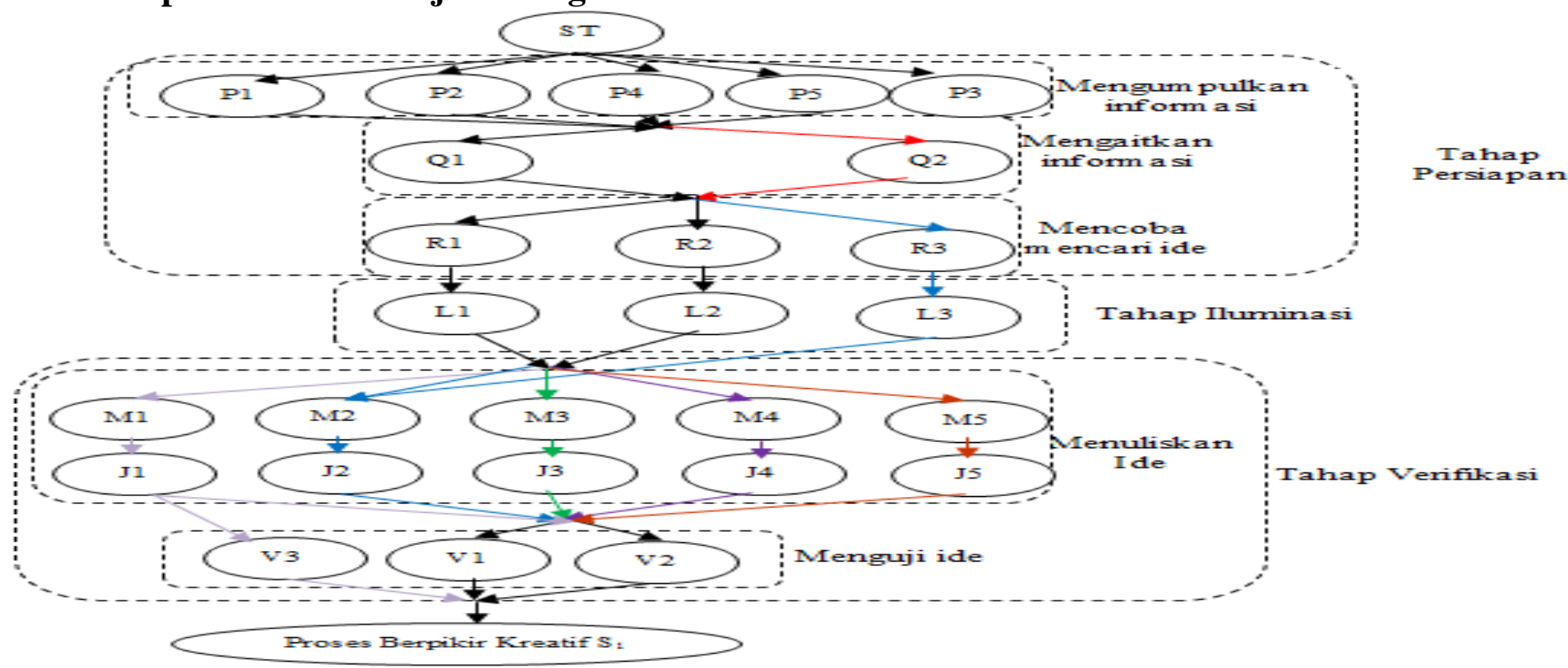

Gambar 5. Struktur Proses Berpikir Kreatif S1 dalam Aktivitas Pengajuan Masalah Matematika 
Keterangan :

$\longrightarrow$ : Alur berpikir pengajuan masalah matematika nomor 1, 2, 3, 4, dan 5

$\longrightarrow$ : Alur berpikir pengajuan masalah matematika nomor 3

$\longrightarrow$ : Alur berpikir pengajuan masalah matematika nomor 1, 2, 3, dan 5

$\rightarrow$ : Alur berpikir pengajuan masalah matematika nomor 4

Alur berpikir pengajuan masalah matematika nomor 1

$\longrightarrow$ : Alur berpikir pengajuan masalah matematika nomor 5

$\longrightarrow$ : alur berpikir pengajuan masalah matematika nomor 2

Berdasarkan gambar di atas dan proses berpikir kreatif yang dikemukan oleh Wallas (Siswono, 2004; Hering, dkk, 2009; Lau, 2011: 21; Sriraman, dkk, 2013), pada tahap persiapan, subjek dapat memahami TPMM yang diberikan meskipun belum pernah mendapat tugas ini. Subjek mampu memahami dan menjelaskan informasi yang terdapat pada gambar geometri yang diberikan serta maksud dari TPMM. Subjek mengetahui bahwa paving blok berbentuk persegi dan persegi panjang, ukuran paving blok persegi panjang dalam rangkaian sama serta 4 paving blok persegi panjang dan 1 paving blok persegi membentuk 1 rangkaian paving persegi. Selain itu, subjek juga mengetahui bahwa paving blok persegi panjang sama dengan dua kali paving blok persegi. Namun informasi ini tidak digunakan subjek pada pembuatan soal matematika. Selanjutnya pada tahap ini, subjek memikirkan tugas yang diberikan, yaitu mengaitkan informasi yang diketahui dengan pengetahuan yang dimiliki (materi dan soal yang pernah dipelajari sebelumnya) serta mencoba untuk mencari ide (menentukan bilangan, redaksi kalimat, atau modifikasi gambar yang akan digunakan). Subjek mengaitkan gambar geometri yang diberikan dengan materi luas (soal nomor 1 dan 4), pola bilangan (soal nomor 2), sistem persamaan liniear dua variabel (soal nomor 3), dan materi perbandingan khusunya skala (soal nomor 5). Setelah memikirkan materi yang berkaitan dengan gambar geometri, subjek mengingat soal-soal yang pernah dikerjakan sebelumnya (kecuali pada pengajuan soal nomor 4). Kemudian subjek mencoret-coret pada kertas atau pada gambar untuk menentukan bilangan yang akan digunakan pada soal. Serta mencari ide kalimat soal berdasarkan soal yang pernah dikerjakan sebelumnya.

Ketika mengerjakan TPPM terkadang subjek terlihat seperti meninggalkan sejenak tugas yang diberikan. Subjek terlihat cenderung diam, melihat gambar kembali, mencoret-coret kertas, memegang jilbab, memegang dahi atau melamun melihat ke arah lain. Namun ketika dilakukan eksplorasi dengan wawancara didapatkan data bahwa subjek masih memikirkan tentang tugas yang diberikan, yaitu mengaitkan informasi dengan materi dan soal yang pernah dipelajari sebelumnya serta mencoba mencari ide untuk mengajukan soal dengan mennetukan bilangan, redaksi kalimat atau modifikasi gambar. Padahal, tahap inkubasi terjadi ketika tidak ada usaha yang dilakukan secara langsung untuk menyelesaikan masalah dan meninggalkan sejenak kegiatan yang dilakukan (Solso, dkk, 2008:446). Hal ini berarti, subjek tidak melewati tahap inkubasi.

Pada tahap iluminasi, terlihat wajah subjek tersenyum tipis seperti medapatkan sesuatu. Di saat itulah, subjek mendapatkan ide mengenai bilangan atau kalimat yang akan digunakan pada soal matematika yang diajukan. Pada tahap verifikasi, subjek menuliskan dan menguji ide. Subjek menuliskan 5 soal matematika. Subjek mengecek soal yang dibuat dengan menjawab soal tersebut, subjek merasa yakin soal yang dibuat benar ketika soal dapat dijawab. Subjek juga memeriksa jawaban yang dibuat dengan menghitungnya berulang-ulang kali dan menggunakan cara lain. Selain itu, subjek memeriksa bilangan yang ada pada soal dengan memeriksa bilangan yang ada pada soal, yaitu mengganti yang diketahui pada soal dengan bilangan yang diperoleh pada jawaban. Misalnya, pada soal nomor 3 subjek menggunakan jawaban yang diperoleh yaitu harga paving blok persegi untuk mencocokkan harga 3 susunan rangkaian paving blok pada soal seharga Rp. 79.500. 


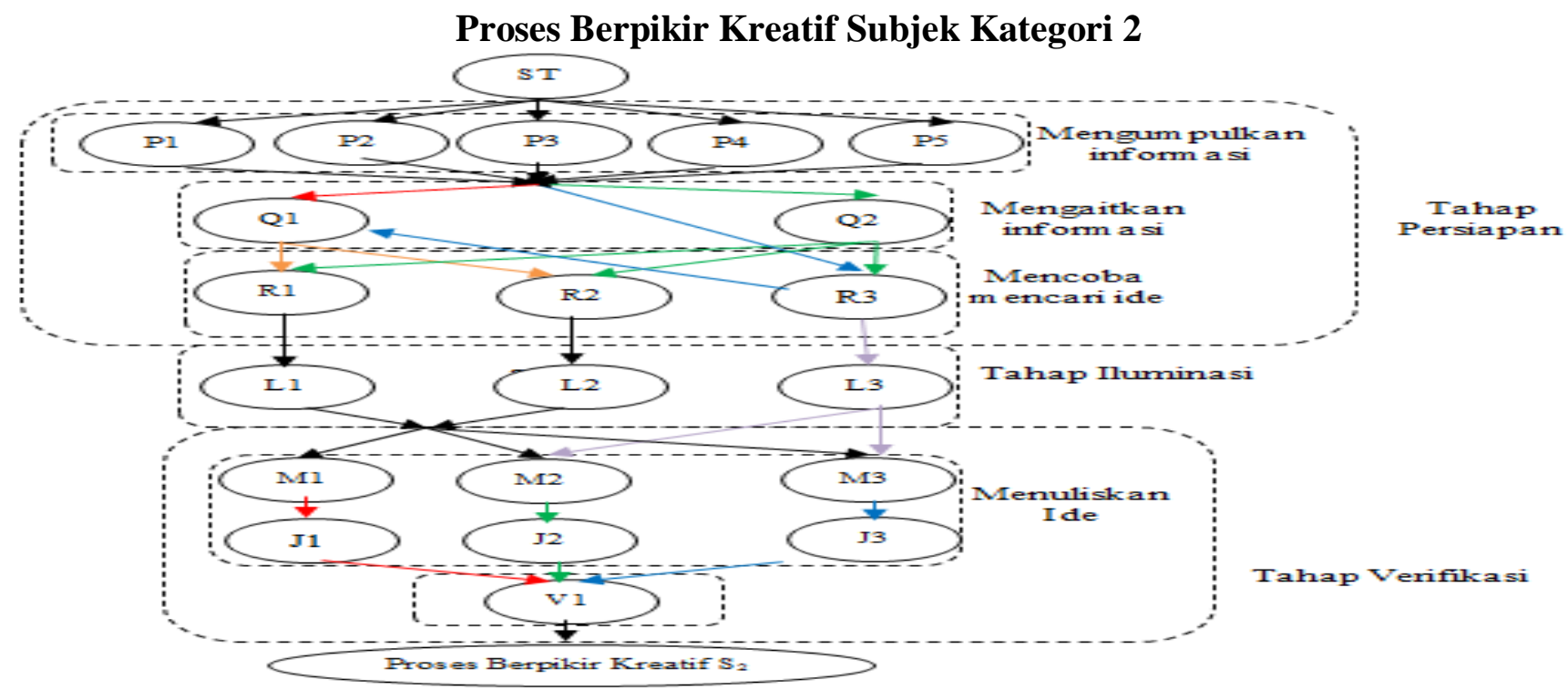

Gambar 6. Struktur Proses Berpikir Kreatif S2 dalam Aktivitas Pengajuan Masalah Matematika

Keterangan :

$\longrightarrow:$ Alur berpikir pengajuan masalah matematika nomor 1
$\longrightarrow:$ Alur berpikir pengajuan masalah matematika nomor 1 dan 3
$\longrightarrow:$ Alur berpikir pengajuan masalah matematika nomor 2
$\longrightarrow:$ Alur berpikir pengajuan masalah matematika nomor 2 dan 3
$\longrightarrow:$ Alur berpikir pengajuan masalah matematika nomor 3
Alur berpikir pengajuan masalah matematika nomor 1,2 dan 3

Berdasarkan gambar di atas dan proses berpikir kreatif yang dikemukan oleh Wallas (Siswono, 2004; Hering, dkk, 2009; Lau, 2011: 21; Sriraman, dkk, 2013), pada tahap persiapan, subjek dapat memahami TPMM karena subjek pernah mendapatkan tugas seperti ini ketika duduk di kelas VIII. Subjek mampu memahami dan menjelaskan informasi yang terdapat pada gambar geometri yang diberikan serta maksud dari TPMM. Subjek mengetahui bahwa paving blok berbentuk persegi dan persegi panjang, ukuran paving blok persegi panjang dalam rangkaian sama, ukuran paving blok persegi panjang dua kali paving blok persegi serta 4 paving blok persegi panjang dan 1 paving blok persegi membentuk 1 rangkaian paving persegi. Selain itu, subjek menggunakan semua informasi yang subjek ketahui dari gambar geometri untuk mengajukan masalah matematika. Selanjutnya pada tahap ini, subjek mengaitkan gambar geometri yang diberikan dengan materi luas (soal nomor 1) dan materi kesebangunan (soal nomor 3). Namun pada soal nomor 3, sebelum subjek mengaitkan pada materi kesebangunan, subjek memodifikasi gambar yang diberikan dengan membagi dua rangkaian paving blok persegi pada bagian diagonal. Sehingga didapatkan segitiga seperti pada soal nomor 3. Pada soal nomor 2, subjek mengingat soal yang pernah dikerjakan sebelumnya dan memodifikasi gambar sesuai dengan soal yang akan subjek buat yaitu tentang jumlah deret geometri tak hingga. Setelah memodifikasi gambar, subjek memikirkan materi atau soal yang berkaitan dengan gambar geometri tersebut, subjek memikirkan bilangan yang akan digunakan pada soal tanpa mencoret-coret pada kertas (soal nomor 1) atau mencoret pada kertas (soal nomor 2 dan 3). Kemudian, mencari ide kalimat soal dengan menggunakan kata-kata subjek sendiri, kecuali pada soal nomor 2.

Awalnya peneliti mengira subjek mengalami tahap inkubasi. Aktivitas subjek seperti meninggalkan sejenak tugas yang diberikan, yaitu cenderung diam, melihat gambar berkali-kali, mencoret-coret kertas, menggaruk bahu/hidung, berbicara dengan temannya atau melihat ke arah lain. Namun ketika dilakukan eksplorasi dengan wawancara didapatkan data bahwa S2 masih memikirkan tentang tugas yang diberikan yaitu mengaitkan informasi yang diketahui dengan materi atau soal yang pernah dikerjakan sebelumnya serta mencoba mencari ide untuk mengajukan soal dengan menentukan bilangan, redaksi kalimat atau modifikasi gambar yang akan digunakan pada soal. Padahal menurut Solso, dkk (2008:446), tahap inkubasi terjadi dimana tidak ada usaha yang dilakukan secara langsung untuk menyelesaikan masalah dan meninggalkan sejenak kegiatan yang dilakukan. Hal ini berarti pada subjek tidak terjadi tahap inkubasi. 
Pada tahap iluminasi, terlihat wajah subjek terkejut dan tersenyum lebar seperti medapatkan sesuatu. Di saat itulah, subjek mendapatkan ide mengenai bilangan, kalimat ataupun gambar yang akan digunakan pada soal matematika yang diajukan.

Pada tahap verifikasi, subjek menuliskan dan menguji ide. Subjek menuliskan 3 soal geometri. Subjek mengecek soal yang dibuat dengan menjawab soal tersebut, subjek merasa yakin soal yang dibuat benar ketika soal dapat dijawab. Subjek juga memeriksa jawaban yang dibuat dengan menghitungnya berulang-ulang kali. Namun, subjek sama sekali tidak membaca soal yang dibuat.

\section{Proses Berpikir Kreatif Subjek Kategori 3}

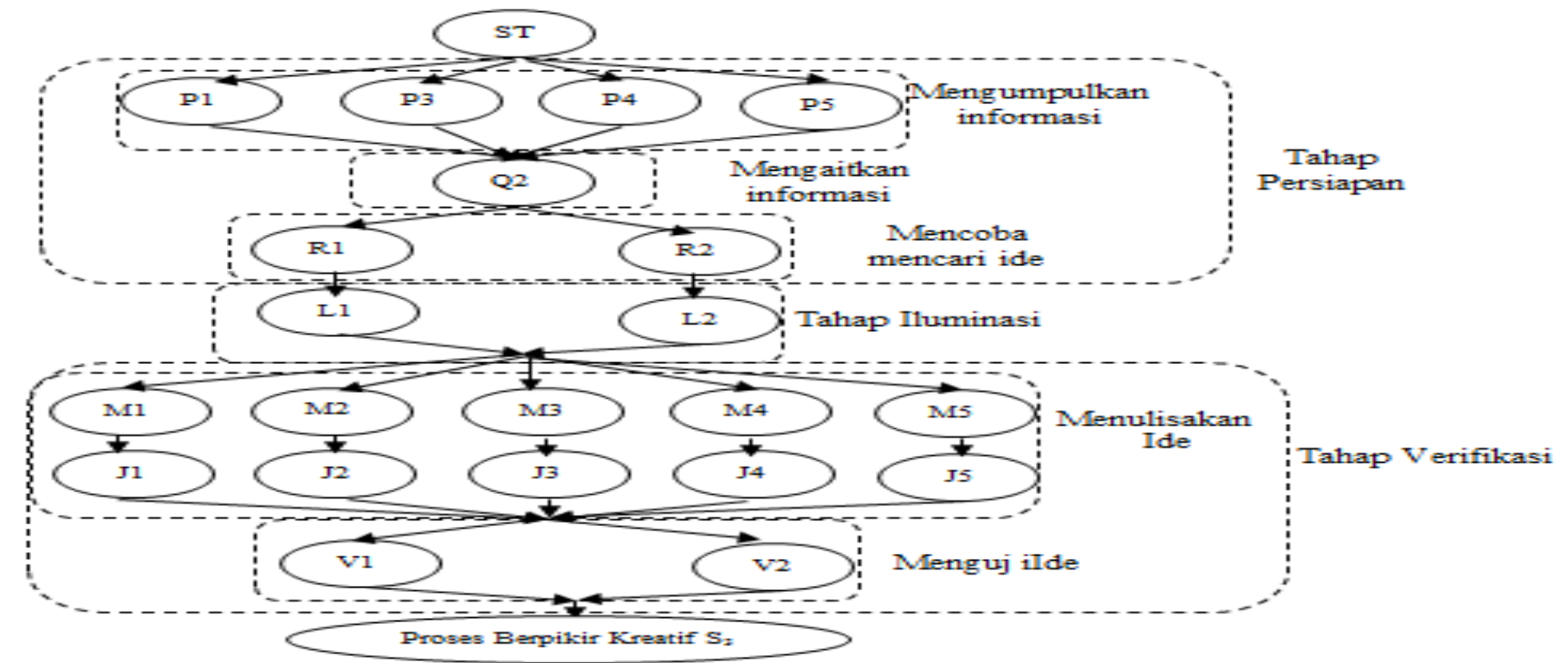

Gambar 7. Struktur Proses Berpikir Kreatif S3 dalam Aktivitas Pengajuan Masalah Matematika

\section{Keterangan :}

$\longrightarrow$ : alur berpikir pengajuan masalah matematika nomor 1, 2, dan 3

$\longrightarrow$ : alur berpikir pengajuan masalah matematika nomor 1

$\longrightarrow$ : alur berpikir pengajuan masalah matematika nomor 1 dan 3

$\longrightarrow$ : alur berpikir pengajuan masalah matematika nomor 2

: alur berpikir pengajuan masalah matematika nomor 2 dan 3

$\longrightarrow$ : alur berpikir pengajuan masalah matematika nomor 3

Berdasarkan gambar di atas dan proses berpikir kreatif yang dikemukan oleh Wallas (Siswono, 2004; Hering, dkk, 2009; Lau, 201: 21; Sriraman, dkk, 2013), pada tahap persiapan, subjek dapat memahami TPMM yang diberikan meskipun belum pernah mendapat tugas ini. Subjek mampu memahami dan menjelaskan informasi yang terdapat pada gambar geometri yang diberikan serta maksud dari TPMM. Subjek mengetahui bahwa paving blok berbentuk persegi dan persegi panjang, ukuran paving blok persegi panjang dua kali paving blok persegi, serta 4 paving blok persegi panjang dan 1 paving blok persegi membentuk 1 rangkaian paving persegi. Namun, terdapat 1 informasi yang belum diketahui yaitu paving blok persegi panjang pada rangkaian memiliki panjang yang sama. Hal ini terlihat ketika subjek begitu yakin soal nomor 1 yang dibuatnya benar.Selanjutnya pada tahap ini, subjek mengaitkan gambar geometri yang diberikan dengan soal-soal latihan Ujian Nasional (UN). Hal ini diakarenakan hampir setiap hari subjek mengerjakan latihan soal UN. Subjek mengaitkan gambar geometri yang diberikan dengan soal luas atau keliling bangun datar (soal nomor 1, 3, dan 5), soal aritmetika sosial (soal nomor 2) dan soal perbandingan senilai (soal nomor 5). Dalam pembuatan soal, subjek tidak mengubah gambar geometri yang diberikan. Subjek langsung menggunakan gambar yang diberikan atau hanya mengambil satu bangun dari gambar yang diberikan. Setelah mengingat soal yang berkaitan dengan gambar geometri yang diberikan, subjek memikirkan bilangan yang akan digunakan pada soal tanpa mencoret-coret pada kertas (soal nomor 1, 2 dan 
4) atau mencoret pada kertas (soal nomor 3 dan 5). Kemudian, menyusun redaksi kalimat soal yang akan dibuat dengan mengigat soal yang pernah dikerjakan sebelumnya.

Awalnya peneliti mengira subjek 2 mengalami tahap inkubasi. Aktivitas subjek seperti meninggalkan sejenak tugas yang diberikan, yaitu cenderung diam, melihat gambar kembali, memainkan pena, memegang dahi, memainkan HP atau melihat ke arah lain. Namun ketika dilakukan eksplorasi dengan wawancara didapatkan data bahwa S3 masih memikirkan tentang tugas yang diberikan, yaitu mengaitkan informasi yang diketahui dengan soal yang pernah dikerjakan sebelumnya serta mencoba mencari ide untuk mengajukan soal mengenai bilangan dan redaksi kalimat yang akan digunakan. Padahal menurut Solso, dkk (2008:446), tahap inkubasi terjadi dimana tidak ada usaha yang dilakukan secara langsung untuk menyelesaikan masalah dan meninggalkan sejenak kegiatan yang dilakukan. Hal ini berarti subjek tidak mengalami tahap inkubasi.

Pada tahap iluminasi, terlihat wajah subjek terkejut dan tersenyum seperti medapatkan sesuatu. Di saat itulah, subjek mendapatkan ide mengenai bilangan atau kalimat yang akan digunakan pada soal matematika yang diajukan.

Pada tahap verifikasi, subjek menuliskan dan menguji ide. Subjek menuliskan 5 soal matematika. Subjek mengecek soal yang dibuatdengan menjawab soal tersebut, subjek merasa yakin soal yang dibuat benar ketika soal dapat dijawab. Subjek juga memeriksa jawaban yang dibuat dengan menghitung kembali. Selain itu, subjek memeriksa bilangan yang ada pada soal dengan mencocokkan jawaban dengan bilangan yang ada pada soal, yaitu mengganti yang diketahui pada soal dengan bilangan yang diperoleh pada jawaban. Misalnya, pada soal nomor 2 setelah mendapatkan jawaban 333,33, subjek mengalikan jawaban yang diperoleh dengan banyak paving blok. Serta pada soal nomor 3, subjek mengalikan $25 \times 25$.

Pada tahap verifikasi ini, subjek terlihat kurang teliti. Hal ini terlihat ketika subjek yakin dengan soal dan jawaban yang diajukan benar padahal terdapat kesalahan pada soal yang diajukan. Meskipun subjek telah memeriksa kembali soal dan jawaban beserta bilangan yang digunakan, Namun, subjek kurang teliti dalam memberikan informasi yang diberikan. Sehingga terdapat kesalahan pada soal nomor 1 dan 5 .

Terdapat beberapa hal yang menyebabkan kesalahan yang dilakukan subjek dalam membuat soal nomor 1 dan 2. Pada soal nomor 1, subjek memberikan tambahan informasi "dua persegi membentuk satu persegi panjang". Seandainya subjek tidak menambahkan informasi ini maka soal yang subjek ajukan benar. Namun karena informasi ini subjek tambahkan pada soal, maka subjek harus memperhatikan bahwa panjang dan lebar persegi panjang yang subjek buat harus saling berkaitan, yaitu ukuran panjang persegi panjang dua kali ukuran lebarnya. Sedangkan pada soal nomor 5, subjek menggambar persegi namun ukuran yang subjek berikan bukan ukuran persegi namun ukuran bangun segiempat tidak beraturan. Pada soal nomor 5, kesalahan yang dilakukan subjek adalah ukuran yang diberikan tidak sesuai dengan gambar yang diberikan.

\section{SIMPULAN}

Berdasarkan hasil analisis diperoleh bahwa subjek pada masing-masing kategori hanyamelewati 3 tahap proses berpikir kreatif yang dikembangkan oleh Wallas, yaitu persiapan, iluminasi, dan verifikasi. Pada tahap persiapan, Subjek pada kategori 1 dan kategori 2 memahami semua informasi yang terdapat pada situasi yang diberikan, namun subjek pada kategori 3 tidak mengetahui 1 informasi. Selain itu, pada tahap ini masing-masing-masing subjek memiliki keunikan dalam mengajukan masalah. Subjek pada kategori 1 mengingat materi atau soal sebelumnya untuk memperoleh ide soal, subjek kategori 2 tidak hanya mengingat materi atau soal sebelumnya namun juga memodifikasi gambar yang diberikan dan subjek pada kategori 3 hanya mengingat soal-soal yang pernah dikerjakan sebelumnya. Ketiga subjek pada masingmasing kategori tidak mengalami tahap inkubasi. Meskipun subjek mengerjakan hal lain yang tidak berkaitan dengan TPMM, subjek tetap memikirkan tugas yang diberikan. Pada tahap iluminasi, masingmasing subjek memperoleh ide untuk mengajukan soal dari situasi yang diberikan dan dikaitkan dengan struktur pengetahuan subjek. Pada subjek kategori 1 mengaitkan situasi yang diberikan dengan materi dan soal yang pernah dipelajari sebelumnya, subjek kategori 2 mengaitkan situasi yang diberikan dengan materi dan soal yang pernah dipelajari sebelumnya bahkan dengan memodifikasi situasi yang diberikan, sedangkan subjek kategori 3 hanya mengaitkan situasi yang diberikan dengan soal yang pernah dipelajari sebelumnya. Pada tahap verifikasi umunya subjek memeriksa soal dan jawaban dengan menghitung jawaban dua kali atau memeriksa bilangan pada soal. Selain itu, subjek pada kategori 1 juga memeriksa soal yang dibuat dengan 
membaca ulang. Subjek pada kategori 1 dan 2 merupakan subjek yang paling teliti karena tidak terdapat kesalahan pada soal yang dibuat oleh kedua subjek tersebut. antara lain :

Berikut saran yang ingin peneliti sampaikan terkait hasil penelitian yang telah dilakukan peneliti

1. Pengetahuan tentang proses berpikir kreatif dapat digunakan untuk merancang model atau strategi pembelajaran yang bertujuan mengembangkan berpikir kreatif.

2. Dalam penelitian ini, pemberian TPMM dilakukan pada 9 calon subjek sekaligus, sehingga peneliti kesulitan untuk melihat proses berpikir kreatif siswa ketika mengajukan masalah. Oleh karena itu, jika ada peneliti yang ingin melakukan penelitian yang serupa sebaiknya pemberian TPMM dilakukan perindividu sehingga dapat dilihat lebih rinci proses berpikir kreatif subjek melalui perilaku subjek dan dipertegas dengan wawancara yang berbasis tugas dan video.

3. Deskripsi proses berpikir kreatif siswa dalam aktivitas pengajuan masalah matematika pada penelitian ini masih terbatas pada jenis soal yang diajukan siswa yang mengacu pada aspek pengetahuan, sehingga perlu penelitian lebih lanjut mengenai deskripsi proses berpikir kreatif siswa dalam aktivitas pengajuan masalah dengan jenis soal yang mengacu pada aspek keterampilan.

4. Tahap inkubasi pada penelitian ini tidak muncul, dikarenakan hanya menggunakan satu situasi dan waktu pengerjaan TPPM terlau singkat. Oleh karena itu, jika ada peneliti yang ingin melakukan penelitian yang serupa sebaiknya memberikan situasi lebih dari satu dan memberikan waktu pengerjaan yang lebih lama.

5. Penelitian ini hanya menggunakan pengalaman dan pengetahuan peneliti dalam mengukur berpikir kreatif siswa, sehingga untuk penelitian selajutnya perlu adanya Alat ukur yang lebih akurat dalam mengukur berpikir kreatif siswa khususnya dalam aktivitas pengajuan masalah matematika.

\section{DAFTAR PUSTAKA}

Bonotto, C. \& Santo, L. D. 2015. On the Relationship Between Problem Posing, Problem solving and creativity in the Primary school. Dalam J. Cai \& J. Middleton (Eds.), Mathematical Problem Posing from Research to Efective Practice (hlm. 103-124). NewJersey: Springer.

English, L. D. 1997. Development of fifth grade children's problem posing abilities. Educational Studies in Mathematics, 34, 183-217.

Gomez, J.G. 2007. What do We Know About Creativity?. The Journl of Effective Teaching, 7(1), 31-43.

Hayes, J. R. 1989. Cognitive Models of Creativity. Dalam Glover, J.A, Ronning, R.R., \& Reynolds, C. R. Handbook of Creativity (hal. 133 - 145). New York: Springer.

Herring, S.R., Jones, B.R., \& Bailey, B.P. 2009. Idea Generation Techniques Among Creative Professionals. Proceedings of the 42nd Hawaii International Conference on System Sciences, 1- 10. Manoa, Honolulu.

Jay, E. S., \& Perkins, D. N. 1997. Problem Finding: The Search for Mechanism. Dalam M. A., Runco, (Ed.), The Creativity Research Handbook, 1, 257-293. New Jersey: Hampton Press.

Kemdikbud. 2014. Permendikbud No. 103 tahun 2014 tentang Pembelajaran pada Pendidikan Dasar dan Pendidikan menengah. Jakarta: Kemdikbud.

Kemdikbud. 2014. Permendikbud No. 58 tahun 2014 tentang Kurikulum 2013 Sekolah Menengah Pertama/Madrasah Tsanawiyah. Jakarta: Kemdikbud

Kim, K. H. 2005. Can Only the Intelligent People be Creative. The Journal of Secondary Gifted Education, 16 (2/3), 57 - 66. Waco: Prufrock Press.

Kontorovich, I., Koichu, B., Leikin, R., \& BermAN, A. 2011. Indicators of Creativity in Mathematical problem Posing : How Indicative are They?. ? Dalam M. Avotina, D. Bonka, H. Meissner, L. Ramāna, L. Sheffield \& E. Velikova (Eds.), Proceedings of the 6th International Conference Creativity in Mathematics Education, 120-125.Latvia: Latvia University.

Lau, J. Y. P .2011. An Introduction to Critical Thinking And Creativity. New Jersey : John WileY \& Sons,Inc.

Silver, E. A. 1997. Fostering Creativity Through Instruction Rich in Mathematical Problem Solving and Problem Posing. Zentralbatt fiir Didaktik der Mathematik (ZDM), 29(3), 75-80. 
Siswono, T.,Y.,E. 2004. Identifikasi Proses Berpikir Kreatif Siswa dalam Pengajuan Masalah (Problem Posing) Matematika Berpandu dengan Model Wallas dan Creative Problem Solving (CPS). Buletin Pendidikan Matematika, 6(2), ISSN: 1412-2278.

Solso, R, dkk. 2008. Terjemahan Mikael Rahardanto \& Kristianto Batuadji. Psikologi Kognitif.Jakarta: Erlangga.

Sriraman, B. \&Lee, K. H. 2011. Mathematical Creativity and Mathematics Education. Dalam B. Sriraman \& K.H. Lee (Eds.), The Elements of Creativity and Giftedness in Mathematics, 119-130. Rotterdam : Sense Publishers.

Sriraman, B., Haavold, P., \& Lee, K. 2013. Mathematical Creativity and Giftedness: a Commentary on and review of Theory, New Operational Views, and Ways Forward. Zentralbatt fur Didaktik der Mathematik (ZDM), 45, 215-225.

Sukmadinata, N.S. 2004. Psikologi Kognitif. Surabaya : Srikandi.

Syahnur.2012. Tes Intelegensi dari Wechsler. Tersedia di http://file.upi.edu/direktori/fip/jur._psikologi/syahnur/pd_iv/tes_inteligensi_dari_ wechsler_[compatibility_mode].pdf, diakses 1 April 2016.

Torrance, E.P. 1969. Creativity what Research Says to The Teacher.Washington DC: National Education Asociation. 